\title{
Social Work in Slovakia in the period after $1945^{1}$
}

\section{J. Levická , K. Levická3}

1 The contribution was realized under the financial support of the project APVV-0524-12-identity of Social Work in the context of Slovakia

2 Prof. PhDr. Mgr. Jana Levická, PhD. Works at the Department of Social Work, Faculty of Health Sciences and Social Work, Trnava University

3 Mgr.Katarína Levická currently holds the position of post-doctor at the Faculty of Health Sciences and Social Work, Trnava University

Submitted: 14.12.2015 Revised: 31.1.2016 Accepted: 4.4.2016

\section{Reviewers:}

I. Tomeš

Faculty of Science, Charles University in Prague, Czech Republic

John R.G. Turner

Whole-Self Discovery \& Development Institute (W-SDDI), Grootebroek, The Netherlands

\section{Key words:}

Social Work, Social Care, The Czechoslovak Republic

\section{Abstract:}

This article reflects the development of Slovak Social Work in the context of the political development of the country. The Authors searched for answers to the following questions: Was Social Work really abolished in Slovakia after 1951? Is there evidence casting doubt upon that assertion? The aim of this article is to contribute to overcoming the claim that after 1951 there was a violent abolition of Social Work in the former Czechoslovakia and point out the consequences for the development and current state of Social Work in Slovakia brought on by ignoring events in the given period.

\section{Introduction}

The diversity of problems which Social Work responds to in the long run raises the question as to whether it is possible to build common consensus in defining it (Core 2003; Askeland, Payne 2001; Asquit, Clark, Waterhouse 2005, etc.). Initially theoretical discussion was later expanded to include research focused on the issue of Professional Identity (e.g. Dewe, Ferchhoff, Sherr, Stüwe 1995; Canavan, 2009; Tamm 2010; Leigh 2013; Lorenzetti 2013). The identity of the Profession is presented as a baseline of the nature of the Profession influenced by several internal and external factors allowing varied understanding. In the Slovak environment, the situation is complicated by two factors. The first is that the Profession has not been developed in a straight line. The second is that, so far, the history of Slovak Social Work has not been adequately compiled. As part of the ongoing research focused on the identity of Slovak Social Work, we also focused on revealing 
an historical context for the development of the Profession in Slovakia because the identity of the Profession is to a significant extent affected by its own history and social status (Emmerson 2010). Knowledge of the history of one's own Profession reinforces a sense of professional pride which not only facilitates the creation of a professional identity but is also a prerequisite for personal satisfaction with one's own work and chosen career (Remley a Herlihy 2007).

Our contribution is a response to the claim that the Profession of Social Work was abolished in Czechoslovakia in 1951 (Majchráková 1990; Řezníček 1995) and its renewal came only in 1990 (Matoušek 2001, Žilová 2000, Strieženec 1996, 1999). Based on the reading of events in Social Work in the reporting period (1951 to 1990), we observe that although the development of the Profession was slowed down it was not abolished.

\section{Methods}

In creating this study we used the concept of an identity as a product of social and political action (Brubaker, Cooper 2000). A similar view is shared by Remley and Herlihy (2007) according to whom understanding of the current state of Social Work presupposes a good knowledge of the historical context of the development of the Profession. The aim of the study was to find out how the Slovak Social Work really was developing in the period 1951 to 1990 . In order to meet this goal, we searched for answers to the following questions:

What happened with Social Work in Slovakia after 1951?

Was at least one area of the Profession continued?

Was education of Social Workers abolished at all levels?
What was the preparation for the career of Social Workers?

What were the publication and research activities about Social Work in that period?

How did the missing information influence the current state of the Profession?

The historiographical method was the main research tool used which is based on concrete and critical reflection of absolute claims referring to events from a historical-political perspective (Kocka 1990, Hendel 2005). The subjects of the research were primary and secondary sources dealing with Social Work, Social Services etc. The analyzed sources were books, magazines, legislative standards, methodical materials of the Ministry, etc. Analysis of the practical role of Social Work in Slovakia would be interesting but would not explain the developments in Social Work as a Science and Profession after 1990. For this reason, events associated with education in Social Work and its development in the Slovak Academic environment became the subject of our analysis.

\section{Findings}

In order to be able to analyze what happened in Social Work in Slovakia after the year 1945 first, we have to take a brief glance at the previous era when Social Work was established as a Profession in the former Czechoslovakia.

\section{Historical and political background to the establishment and development of Social Work in Slovakia}

The origins of Social Work in the territory of today's Slovakia are associated with the Austro-Hungarian Empire of which Slovakia was a part until 1918. The attention of the nascent Profession still within Austria-Hungary was mainly focused on the problems of poverty, disability, children and 
families at risk of social pathological phenomena, lonely elderly people, the suppression of socio-pathological phenomena, etc.. In 1918, the common state of Czechs and Slovaks called the Czechoslovak Republic was founded but whose co-existence was interrupted in the period 1939 to 1945 . In 1945, after World War II the Czechoslovak Republic was restored. The termination of the joint State of Czechs and Slovaks came in 1992. Since 1 January 1993, an independent Slovak Republic was founded. Slovak history of Social Work should therefore be examined in the context of the three state units:

The first years of the common state were marked with enthusiasm because of the acquired freedom and desire to build a modern democratic state. The overall state infrastructure was built upon Public Authorities including Ministries, Health, Economics, Education, etc.. In this atmosphere in Czechoslovakia, Social Work also began to develop. The public sensitively perceived the gravity of existing problems the solutions of which were sought by the young Professionals. Therefore, Social Work in Czechoslovakia commanded respect although the term "Social Work" was rarely used during that period.

The very experience gained in the common Austro-Hungarian Empire proved to be an advantage. We would like to mention just a few:

- Slovak women studied at the Viennese Vereinigte Fachkurse für Volkspflege, the first school of Social Work in Austria-Hungary (Mais, 2011; Levická, J., Levická, K. 2015);

- Personal contacts with key representatives of Social Work abroad which were maintained by e.g. Alice Masaryková, Marie-Krakešová Došková and others (Levická J. 1999, Levická et al. 2015, Kodymová, 2013, Brnula, Kodymová, Michelová 2014);
- Entrance of personalities including Juraj von Schulpe, Lew Winter and others in Social Work (Botek, 2009; J. Levická 1999).

Shortly after the establishment of Czechoslovakia, Schools that educated future Social Workers were opened. Already at the stage the possibility of Pre-graduate Studies in the University environment began to be discussed. In the 1930s, the Organization of Social Workers - an umbrella of Social Workers in Czechoslovakia was founded.

\section{Situation after 1945}

In the following part of this article, firstly, we explain the events within the Profession in the years 1945 to 1990, and then point out the consequences of ignorance of the historical context for the development of Social Work in Slovakia after 1990. In this analysis, we pay specific attention to how Social Work Education took place; research and publication background of the then period; or other important events that occurred for Social Work in the territory of the former Czechoslovakia in the years 1945 through 1990.

As a result of World War II, the renewed Czechoslovak Republic was in the so-called Soviet Zone which was shortly after 1945 also reflected in the political direction of the country. Changes being implemented in the country gradually undermined the democratic character of the Republic which finally in 1948 resulted in an open regime change. That regime change was naturally carried over into the total life of society, hence to Social Work. In the area of education policy, the impact of the new policy orientations only gradually became apparent.

Immediately after World War II, part of the Professional Community became active and attempted to bring back Education for 
Social Work which at the time was mainly Sociologically oriented. Based on this initiative, Decree No. 140/1945 was issued which established the Prague University of Political and Social Sciences. It was a four-year Non-University curriculum. The School had a total of three faculties one of which was Social Science. The School was established as a theoretical and practical workplace with the following mission:

1. Freedom of research to study and cultivate Political, Social and Journalistic Sciences.

2. Provide its audience (students) with thorough theoretical and practical knowledge and skills in order to teach them to navigate in society and to work for society; and thus educate not only Scientists, but also practical experts for the above mentioned disciplines.

3. Submit Certificates to the Government and the National Council (in terms of expert's opinions) and proposals on Political, Social and Journalistic matters.

It was assumed that the University would prepare expert's opinions for the Government and National Assembly. Prominent Czechoslovak Sociologists were involved in the teaching staff and Rector of the School was J.S. Rouček, American Sociologist of Czech origin. One part of the School was Social Science which should have prepared experts for the Social sphere. The study included subjects such as Sociology; Social Policy; Social Stratification; Social Psychology and Criminology; Sociology of Families; Children and Marriage; and Social Pathology. The second and third year were focused on Social Work and therefore there were lecture subjects such as Psychogenesis of a Social Case, Methods of Social Work and Social Policy. In 1949, the name was changed to the College of Political and
Economic Sciences, and four years later in 1953 it was abolished (Levická 1999, Kodymová 2013).

The University of Political and Social Sciences had one remote branch in Brno from which later the College of Social Studies was profiled and established by Law No. 124/1947 Coll. Unlike the Prague School, it was focused more on practical performance. It aimed to train personnel for National Committees, experts for Social and Health Administration and Secondary School Teachers. Rector of the Brno College of Social Studies was Arnošt Inocent Bláha and possibly it was his initiative that the study, in addition to Sociologically oriented subjects, also included Social Pathology, Social Policy or Psychology.

In 1949, the Masaryk Medico-Social State School was abolished. Detailed reasons for its abolition are not known, but it is thought that its abolition occurred precisely because of the establishment of Higher Education. However, in 1951, it was decided to abolish Higher Education of Social Workers. Students were allowed to complete their study, thus the last graduates finished studies at both colleges in 1953 .

After 1953, the training of Social Workers was implemented at a Secondary School in Prague which had opened in 1948 and operated until 1959 (Sociální Práce 1996). The original name of the School was the Vocational School of Social and Health Studies. The name of the School was subject to frequent changes. In 1952, the School received the name of the Higher School of Social Studies in Prague, which continued until the Academic Year 1959/60 when it was reorganized into a two-year post-secondary curriculum; the School again changed its name to Secondary School of Social and Law Studies. This change came as a result of the evaluation of four-year Pre-graduate Study where poorly trained but personally mature graduates were leaving to practice. 
Although the school year 1959/60 opened a two-year post-secondary program, students who began study at the four-year school were allowed to complete their study. The last A-level Exams at that School took place in 1962. The extension studies spread to other cities and were basically of two types - focused on Social, or Social and Law Studies.

The resumption of University Studies focused on Social Work came in the years $1987 / 88$, but only as a Specialization in the Study Programs of Sociology and Andragogy. An independent University Study Program was opened only in 1990 (Sociálna práca 1996; Levická, J. 1999; Kodymová 2015).

If the development of the Profession on the basis of these facts is evaluated, it must be recognized that ending the Education of Social Workers in Universities has slowed the development of the theoretical basis of Social Work. The fact that Social Work Education in the years 1951 to 1990 in Czechoslovakia was not situated exclusively within Universities does not entitle anyone to claim that Social Work as a separate teaching discipline did not exist at all in the then circumstances.

The presence of Social Work in Czechoslovak Society in the period under review is shown by the existence of several scientific research units which began to be built in the First Republic while several were established as a Ministerial Department. Their activities continued beyond 1948 albeit sometimes in a modified form. Prior to 1945 , there were Research Departments in Czechoslovakia: Masaryk Academy of Work (1920); Social Institute of Czechoslovakia (1920); Psychotechnical Institute (1921); Central Counseling on Professions in Slovakia, 1928); Institute of Human Labor (1939) (Kodymová 2015; Krajčovičová 2009; Bystrický, Zemko 2004; Tomeš 1996).
After World War II, the following Research Institutes operated in Czechoslovakia:

- Czechoslovak Institute of Labor

- Regional Institute of ČSÚP for Slovakia (1948)

- Research and Training Institute for Occupational Safety (1954) in 2003 it was incorporated into the new organization: Center for Study of Work and Family

- Scientific Research Center in the State Wage Commission

- Czechoslovak Research Institute of Labor (1964)

- Research Institute of Living Standards (1965)

- Research Institute for Social Development and Labor

- Czechoslovak Institute of Labor and Social Affairs (1974)

- Research Institute for Social Development and Labor (1984)

- Research Institute of Labor and Social Affairs established in Bratislava in 1991. In 1992 its name was changed to the Research Institute of Labor, Social Affairs and Family

The results of these reorganizations remained unnoticed after 1990 because after restoring the Pre-graduate Training of Social Workers at the Universities problems on which they focused did not present as interesting to Educators. Only Strieženec (1999; 2006) and Tomeš $(1996 ; 2010)$ paid attention to them. Both of these Authors staunchly understood that Social Work was a practical exercise of Social Policy.

The cause of this factor can be seen particularly in the strong focus of Czech and Slovak Social Work on the Therapeutic or Counseling Paradigm under Navratil's (2001) curriculum. Only over the last decade have the numbers of Authors who are more engaged in Social Work in the context 
of this reform paradigm gradually increasing. In the production of British or American Social Work the paradigm is quite often discussed by Authors including Jane Adams (1922), R. Bailey, M. Brake (1975), Jan Fook (2002), Lena Dominelli (1998, 2002), Neil Thompson (2012) and others. The Academic Community of Social Work being created in the SR did not feel the need for orientation in the area of any reform paradigm as the problems the foreign Authors were coping with were only seen as examples from history at that time. Moreover, in the period immediately after November 1989 in the Czech and Slovak Federative Republic a strong anti-Socialist sentiment prevailed. It was easier and "Socially safe"4 to navigate for the Therapeutic and Counseling Paradigm. Then there only had to come up arguments that during Socialism Social Work suffered an extinction and it was not developed theoretically after 1951; the Authors identified themselves with this claim. This was the main reason that for a long time Slovak and Czech Authors did not deal with the development of Social Work in the period 1951 to 1990 .

Another unaddressed area from which we could learn more about the development of Social Work in Slovakia are publications, including articles in Departmental Journals such as 'Social Security' - a monthly of the Ministry of Labor and Social Affairs. In 1968, in the Annex to this magazine, a paper was published entitled 'Social Worker: Methodical Annual' which also stated that "The study "Social Services" of Bohumir
Šmyd, published by the Research Institute of Social Security in 1966 defines Social Work as a set of activities, the purpose of which is direct efforts, immediately affecting man or his family, to preserve his relationship to society, to his nearest environment, to education, to work, etc. It can be characterized as Socio-diagnostic, Consultative, and Educational Work and Work providing Social Services (organized or directly provided) in particular cases..." (Sociálny Pracovník 1968 p. 3). Although it is subtle material in scope, it is full of surprises in the context of the argument that Social Work was absolutely stagnant in the period after 1951. It reads, for example: The Social Worker is intended solely for socio diagnostic activities in families. Other tasks cannot distract him from his work. Consequently, he does not carry out any Administrative duties: neither does he have the power to make decisions, but only to propose" (Sociálny Pracovník 1968, p. 6).

In addition to the above report by $B$. Smid (1966), in this period papers were published such as Job Content of Regional Head Nurse in Social Services (Majchráková 1957), Job Content of Nurses for Social Services in a Medical Institution for Tuberculosis (Majchráková, Vašečková 1958); Social Service (auxiliary textbooks issued for internal use) Study Purposes of Nurses for Social Services, ZS, DS, ŽS, Head Nurses and Chief Nurses in Medical Facilities (Majchráková 1971 and repeatedly until 1987); Forms and Methods of Social Work (auxiliary textbooks)

${ }^{4}$ For neutral evaluation of the period 1951-1989 (if possible) socio-political atmosphere was not appropriate. At a time when society refused everything that was somehow associated with the previous regime it was literally unwanted to talk about some positives that actually happened during that period. Therefore, we used the term "Socially safe" which indicates that in some of the teachers there were (though unfounded) fears related to the freedom of speech; as if they still did not manage to believe that the academic ground is free and open space for critical discussion. We believe that 25 years is enough of a time gap prerequisite for an objective assessment of that period. 
(Majchráková 1981); Tasks of Social Workers in Alcoholism Treatment Centers (textbooks) (Skála, Mat'ová 1973); Methods for Working with the Elderly by Schimmerlingova (1972)'; a two part work on Educational Therapy by Krakešova (1973); Problems of Families and Family Therapies by Fiso (1980); Methods of Social Work I and II by Chravatova and Brabcova which were published repeatedly (1975, 1985,1991). The Ministry issued many interesting methodical materials and guides on the tasks of Social Workers such as Caring for Socially Inadaptable People. A methodological tool for the staff of National Committees (1983); Work with the Gypsy Population (1976); Care for Citizens with Reduced Capacity to Work (1987); Proposed Principles for Completion of a Comprehensive System of Post-prison Care (1985); etc. In preparing these materials Authors also included Anglo-Saxon literature, as our Social Work maintained links to Social Work implemented mainly in the US and UK. After 1969, the Sociálna/ Sociální Politika Journal published many good articles focusing on current issues in Social Work.

The above publications are only examples, illustrative in nature, in which we want to substantiate our claim that Social Work in the Territory of Slovakia, or Bohemia, also developed in the period 1951 to 1989. At the same time, it is illustrated by the selected examples that these studies were created in each decade of the reporting period.

In practical terms, Social Work developed most within the Health Service. Ironically, it is in this field of Social Work where the roots of the claims about termination of Social Work after 1951 can be found. According to the claims of one of the most important representatives of Social Work in the Health Service, Helena Majchrákovek (1990 p. 7) wrote "Due to this simplified looking at Environmental and Social needs of human beings, in 1951 healthcare abolished: a) the branch of Social Nurses; b) the concept of Social Services; c) the statistical number of Social Nurse.... Professional literature with Social issues ceased to be issued". However, the truth is that already in 1952 instead of Social Nurses, Nurses for Social Services appeared with the consent of the Ministry of Health, so there was only a change in job title. Another paradox is that shortly after the abolition of Higher Education for Social Work and Education conducted at Universities, the Ministry of Health initiated the establishment of a post-A-level Curriculum in Health-Social Work.

The allegation of termination of Social Work in Czechoslovakia as a consequence of the onset of Socialism was associated with the termination of the Ministry of Labor and Social Affairs in 1957. The Ministry, with a new name Ministry of Labor, Social Affairs and Family, was restored only in 1968.

It is interesting that after the restoration of that Ministry in 1968, the activities of The Society of Social Workers were restored. The revival of the Society was initiated by its former members who operated either in direct practice with clients or at secondary schools specialized in Social Care. In the same year, the Society began to develop activities aimed at the resumption of higher education for Social Workers (Sociální Práce, 1996).

\section{Developments in the Field of Education of Social Workers after 1990}

In the Slovak literature on Social Work there can be found allegations that after Social Work had been abolished in the Czechoslovak Socialist state it was rebuilt after 1990. Based on our findings in recent years, however, we object to this claim and suggest to talk about the reconstruction of the Social Work Profession after 1990. There is no doubt about the fact that the abolition 
of Vocational and Higher Schools of Social Work slowed the development of the Profession in its Theoretical and Practical Levels, however, did not mean its extinction.

The Education of Social Workers at Public Universities was reopened in 1990. During the next five years, the study programs gradually opened at the Pedagogical Faculty of the Comenius University in Bratislava; the Faculty of Arts of Prešov University; the Faculty of Nursing and Social Work, Trnava University (in 1997, they changed the name of the faculty to Faculty of Health and Social Care); the Faculty of Social studies of Constantine the Philosopher University in Nitra; at the Pedagogical Faculty of Matej Bel University in Banska Bystrica. Later, these were joined by other Public (State) Universities, which opened Study Programs in Social Work.

Increased interest by young people in this study of Social Work immediately also stimulated the emergence of some Private Universities of which the most famous include the University of St. Elizabeth in Bratislava and Danubius University in Sládkovičovo.

The development of Higher Education for Social Workers is also linked to the need for the preparation of University textbooks, monographs, study texts, which are closely related to research oriented Social Work. Gradually, there appeared also works assessing the development of the Profession in the period 1945 to 1990 (Majchráková 1990; Novotná, Schimmerlingová 1992; Řezníček 1995 and others); and these publications allege that after 1951 the extinction of Social Work in Czechoslovakia occurred. This claim was subsequently adopted by a variety of Authors (Strieženec 1996, 1999; J. Levická 1999, 2002; Matoušek 2001, 2005; Brnula 2012; Navrátil 2001; Oláh, Schavel, Ondrušová 2008 etc.) and greatly influenced the development in the Profession in Slovakia and the Czech Republic.

Based on the results of content analysis focused on the period after 1990, we conclude that ignoring the nearly 40 years of Social Work in Czechoslovakia caused a weakening of identity and Social status of Social Work. Social Work even today is seen by a part of the public as work which does not need any Professional training.

For the first decade (1990 to 2000) reconstruction of the Social Work Profession is characterized by its building "from the outside" which was the result of lack of Academics and Researchers in Social Work. Among Teachers who contributed to Education of Social Workers in Slovakia in that period there was not one Teacher who had studied Social Work. Therefore, they did not have even necessary theoretical knowledge in the field of Social Work. The persistent claim that

anyone can do Social Work was complemented by the argument that Social Work can be taught by anyone.

An emerging change in this area can be registered around 2000 when the first graduates of the Study Program in Social Work were accepted for Doctoral Studies ${ }^{5}$. These Doctoral Students were internally strongly identified with Social Work and eager to develop the theoretical basis of the Profession

5 The first doctoral program for Social Work opened at the Faculty of Nursing and Social Work (now the Faculty of Health and Social Work) of Trnava University, which also housed the first Doctoral Committee for the whole Slovakia. Chairman and Members of the Committee were appointed (or dismissed) by the Minister of Education. Members of the Committee could have been proposed by individual Departments so as to be represented and participate in the activities of the Committee. 
thanks to which new publications focused on Social Work emerged.

Inadequately nurtured at a local level seems to be a natural consequence of the situation. Critically, it must be admitted that the so-called Post-secondary Schools, which had implemented Post-A-level Studies focused in Social Work for years in the early 90s graduated better prepared Teachers for Social Work compared to Universities. However, Teachers from these schools were not interested to work in a University environment, which requires Scientific Studies. The vast majority of classical, academically oriented University Professors dedicated their Scientific attention to areas in which they worked before 1990, for example Medicine, Psychology, Law, Education, Sociology and so on. Only some of them decided to change their Professional orientation, and therefore, the first years of the building of Social Work at Slovak Universities were marked by an intense familiarizing with Social Work. Individual Social Work Departments gradually recruited Practitioners who complemented their Education. In the first decade of renewal of Higher Education in Slovakia you will hardly find any research focused on Social Work if qualifying studies are not taken into account.

In Slovakia, consensus on the theoretical basis of the Profession had been absent in the long run, which was already demonstrated in discussions about the content of the curriculum for future Social Workers. Study Programs reflected the more subjective interests of some Teachers than the real needs of students and the requirements of Practice. The absent consensus on what should constitute a curriculum for Social Work was reflected not only in the lack of pertinent literature but also in the underdeveloped theoretical basis of Social Work. Joint development of minimum training standards for the qualifying Social Workers and their acceptance by the Ministry of Education in 2003 also was positively reflected in the creation of Professional literature, where a qualitative shift can be observed in recent years (e.g. Balogová 2011; Brnula 2012; Gabura 2012; Gabura, Mydlíková 2004; Levická et al. 2012; Levická, J., Levická, K. 2015; Matulayová, Musil 2013; Mátel 2010; Mydlíková 2013; Rusnáková, Szaboová 2013; Vaska 2012 and others.).

\section{Conclusion}

Between 1950 and 1989, the Social Work Profession was not abolished, but its development was strangled. Stopping University Education was reflected in the development of theoretical foundations for Social Work. Paradoxically, although there was a strong emphasis on labor, labor conditions of workers and the like, research activities were not stopped in our country. Research activities showed comparable activity with similar Research Institutions abroad. It is indisputable that during this period Social Work continuously developed in the Health Sector and State Administration. Also, the requirements for the Education of Social Workers in connection with this were changed. Some activities carried out by Social Workers before that period were gradually taken over by other Professions, particularly Psychologists and Clinical Social Scientists (Majchráková 1990; Balogová 2002; Brnula 2012; Levická 1999, 2002a; Oláh et al. 2008, 2009; Strieženec 1996, 1999; Tokárová et al. 2002; Žilová 2000).

In the recent period, Authors focused on Social Work have recognized the urgent need for regular reflection on the impact of differences between Theory and Practice in the development of the Profession. In each area there are natural differences between Theory and Practice. In the case of Social Work, however, the differences exceeded the normal rate. This situation was caused by the fact that in the Educational Process 
students were familiarized with the Theory and Practice implemented in significantly different environments. Educators strove to transfer the "current state of knowledge in the world " which is unquestionably a duty of University Teachers, but, in many cases, with the lack of reflection on domestic reality. Students, especially part-time students, accepted only with difficulty different pictures of Social Work which they were discovering in Theory and in Practice. They did not understand the too great differences between "Scientific" and "Practical" Social Work which evoked feelings, on a part of some students that theoretical knowledge was unusable in practice. These differences further blurred the identity of the Social Work Profession, a situation which persisted for more than ten years before it began to gradually change.

Despite best efforts it has failed to create a clear picture of the Profession. The public does not know what is under the name of Social Work and what can realistically be expected from Social Workers. We confirm the validity of the argument that the characterization of Social Work as a Profession aims to help a person in a difficult situation, blurs, rather than clarifies, the image of the Profession (Gelles, Clark et al. 2007, Maron 2003). The increase in field offices preparing future Social Workers contributed to the unclear picture of Slovak Social Work. This trend peaked around 2000. The official cited reasons for their opening was to bring University Education closer to poorer regions in order to save travel costs for students. These offices were opened by Public and Non-public Universities and Colleges. Due to the short period of time during which they were established, in several cases, there were no quality teaching collectives; the learning in some offices was not always in line with the latest knowledge in the field of Social Work. Moreover, these offices only rarely employed knowledgeable individuals who would pursue Scientific as well as Educational Work.

Orientation on the quantity of curricula for Social Work has resulted in the number of Graduates who flooded the labor market in a short time did not correspond with the needs of Practice; moreover, a relatively large number of these Graduates received a diploma without the knowledge corresponding with standard requirements for the training of Social Workers ${ }^{6}$. The media have brought information on the number of students who graduate from Universities each year and the lack of experts in Practice. This information is often associated with questioning the legitimacy of the Profession, claiming that students finishing their studies are not actually interested to carry on the Profession and so on.

There has been a lack of reliable information on the causes of this situation. The unilaterally targeted information strengthen the vague idea of the Profession, tasks, objectives and responsibilities of its representatives.

The status of Social Work in the Slovak public, following the introduction of Higher Education has paradoxically worsened compared to the period before 1990 which is partly caused by the fact that Social Work is the worst paid Profession with a University Degree required in the Slovak Republic.

${ }^{6}$ Developments in Pre-graduate Studies in Social Work after 2000 require quality secondary analyses in order to draw valid conclusions. For this reason, and also due to the sensitivity of the issue, we do not provide specific identifying information through which specific work places could be identified. 


\section{References}

1. ADDAMS, J. (1922) Peace and Bread in Time of War. [online]. New York: Macmillan. [cit.2013-11-4]. https://archive.org/details/ peacebreadintime22adda

2. BAILEY, R.; BRAKE, M. (1975) Radical Social Work New York: Pantheon Books

3. BALOGOVÁ, B. (2002) Introduction to Social Work. Prešov University of Prešov

4. BALOGOVÁ, B. (2011) The meaning of life. Beograd: Academy of Serbian Orthodox Church

5. BOTEK, O. (2009) Social policy for social workers. Piešt’any: PN, 2009

6. BRNULA, P. (2012) Social work. History, theory and methods. Bratislava: IRIS

7. BRNULA, P.; KODYMOVÁ, P.; MICHELOVÁ, R. (2014) Marie Krakešová pioneer Theory of Social Work in Czechoslovakia. Bratislava: IRIS

8. BYSTRICKÝ,V., ZEMKO, M. (Eds.) (2004) Slovakia in Czechoslovakia. Bratislava: Since

9. DOMINELLI, L. (2002) DeProfessionalising Social Work Anti-oppressive practice, Pcompetencies and postmodernism. In: British Journal of Social Work, 26, 2. p. 153-175

10. DOMINELLI, L.(1998) Sociology for Social Work. Basinstoke: Macmillan

11. EMERSON, C. H. (2010) Counselor Professional Identity: Construction and Validation of the Counselor Professional Identity Measure. [online]. Dissertation thesis. Greensboro: FGS, University of Norths Carolina, 274pp. [cit.2015-01_03]. http://libres.uncg. edu/ir/uncg/f/emerson_uncg_0154d_10396. pdf

12. FOOK, J. (2002) Social Work: Critical Theory and Practice. London Sage Publication Ltd

13. GABURA, J. (2012) Theory families and the process of working with the family. Bratislava: IRIS

14. GABURA, J., MYDLÍKOVÁ, E. et al. (2004) The management of social case. Bratislava: ASSP
15. GABURA, J., PRUŽINSKÁ, J. (1995). Counseling process. Prague: Slon

16. GELLES, R.; CLARK, E. et al. (2007) Scattered Image: Perspectives on Social Work's Identity Challenge, Social Impact Magazine, 2007 Washington University in St. Louis. HALL, N., HEALY, L.M. (2007) 'International Organizations in Social Work', In WAGNER.L., LUTZ, R. (eds) Internationale Perspektiven Sozialer Arbeit [International Perspectives in Social Work], pp. 223-42. Frankfurt: IKO-Verlag.

17. HEALY, L. M. (2008) International Social Work: Professional Action in an Interdependent World. 2nd ed. New York: Oxford University Press

18. HENDEL, J. (2005) Qualitative research. Basic Methods and Applications. Praha: Portál, $408 \mathrm{~s}$.

19. CHARVÁTOVÁ, D., BRABCOVÁ, V. (1975) Social Work Methods I-II. Praha: SPN

20. KOCKA, J. (1990) Geschichte wozu? In HARDTWIG, W. (Hg.). 1990. Über das Studium der Geschichte. München: Deutcher Taschenburg Verlag, s.427-443

21. KODYMOVÁ, P. (2013) Czech history of social work in the years 1918 - 1948. Prag: Karolinum, 132 s.

22. KOVÁČIKOVÁ, D. (2000) Basic questions of history of social work. Žilina: Žilinská univerzita, $101 \mathrm{~s}$.

23. KRAJČOVIČOVÁ, N. (2009) Slovakia towards democracy. Bratislava: HÚ SAV

24. KRAKEŠOVÁ-DOŠKOVÁ, M. (1946) Psychogenesis social case. The emergence of social abnormality. Prague: A New Awareness 1946. 343 s.

25. KRAKEŠOVÁ, M. (1973) Educational therapy. Part I and II. Prague: MPSV 10.1177/0020872814547438

26. LEVICKÁ, J. (1999) Outline history of social work. Trnava: SAP $104 \mathrm{s.}$

27. LEVICKÁ, J. (2002a) Theoretical Aspects of Social Work. Trnava: ProSocio, 2002, 283 s. 
28. LEVICKÁ, J., LEVICKÁ, K. (2015) Case Social Work - the creation and development. Hradec Králové: Gaudeamus

29. LEVICKÁ, J., LEVICKÁ, K., HANZALÍKOVÁ, V., BÁNOVČINOVÁ, A. (2012) Ekosociálne approaches in social work. Trnava: Oliva, 2012

30. LEVICKÁ, J. ZEMAN, K. (1999) Social protection of children and young people. Bratislava: Faculty of Nursing and Social Work TU v Trnave

31. MACHAČOVÁ, M. (1969) Social and legal protection. Fundamentals and Methods - General section. Prague: SPN, 2.přepr. vyd. $126 \mathrm{~s}$.

32. MACHAČOVÁ, M. (1966) Social and legal protection. Methods - part special. Prague: SPN, 2.vyd. 1966. $112 \mathrm{~s}$.

33. MAIS, M. (2011) Ilse Arlt - The Austrian Pioneer of Poverty and Welfare Research Based Social Work Theory and Practice. In: Social Work and Society International Online Journal, 9, 2011, 2

34. MAJCHRÁKOVÁ, H. et al. (1990) Social services and health-social care population. Martin: Osveta

35. MÁTEL, A. et al. (2010) Ethics of social work. Bratislava: University of Health and Social Work, st. Elizabeth

36. MATOUŠEK, O. et al. (2001) Basics of Social Work. Prague: Portál

37. MATOUŠEK, O. et al. (2005) Social work in practice. Prague: Portál

38. MATULAY,S., MATULAYOVÁ.T. (1998) Social Work - Selected Chapters. Nitra: UKF MATULAYOVÁ, T., MUSIL, L. (2013) Social Work, Education and Postmodernity. Theory and Studies in Selected Czech, Slovak and Poish Issues. Liberec: Technical University of Liberec

39. MYDLÍKOVÁ, E. (2013) Family in the context of cognitive-behavioural theories. Warszawa: Wydavnictwo Naukowe PWN $112 \mathrm{~s}$

40. NAVRÁTIL, P. (2001) Theory and Methods of Social Work. 1. vyd. Brno: MZ, 2001.
162 s. NOVOTNÁ, V., SCHIMMERLINGOVÁ, V. (1992) Social work, its development and methodological procedures. Prague: Karolinum

41. OLÁH, M.; SCHAVEL.M.; ONDRUŠOVÁ, Z. (2008) Introduction to the study of history and social work. Bratislava: University of Health and Social Work, st. Elizabeth

42. REMLEY, T .P., HERLIHY, B. (2007) Ethical, Legal and Professiola Issues in Counseling. New Jersey: PearsonMerrill Prentice Hall

43. RUSNÁKOVÁ, M., SZABÓOVÁ, M. (2013) Parenting from the perspective of young adults from children's homes. Libreria Ateneo Salesiano (LAS)

44. ŘEZNÍČEK, I. (1995) Methods of Social Work. Prague, SLON 1995. 75 s.

45. SOCIAL WORK. Manual social worker (1996) Prague: MPSV Society for Social Workers Social Work (1968) Methodological Guide. It occurred as a supplement monthly "Social security". Bratislava: Press and publicity department MPaSV

46. Social worker. (1968) Methodological Guide. Completion. It occurred as a supplement monthly "Social security". Bratislava: Press and publicity department MPaSV

47. STRIEŽENEC, Š. (1996) Dictionary social worker. Trnava: AD

48. STRIEŽENEC, Š. (1999) Introduction to Social Work. Trnava: AD 215 s.

49. THOMPSON, N. (2012) Anti-Discriminatory Practice. Equality, Diversity amd Social Justice. 5th ed. London: Palgrave Macmillan

50. TOMEŠ, I. (2010) Introduction to the theory and methodology of social policy. Prague: Portál

51. TOMEŠ, I. (1996) Social policy - theory and international experience. Prague: Socioklub

52. TOKÁROVÁ, A. et al. (2002) Social work. Chapters from the History, Theory and Methodology of Social work. Prešov: FiF PU 2002. $572 \mathrm{~s}$. 
53. VASKA, L. (2012) Theoretical aspects of starting supervision of social workers. Bratislava: IRIS

54. ŽILOVÁ, A. (2000) Chapters from the theory of social work. Žilina: Edis

\section{Corresponding author}

prof. Mgr. Mgr. Jana Levická, Ph.D.

Department of Social Work FZaSP

University of Trnava

Hornopotočná 23

91843 Trnava, Slovakia 